\title{
A study on the impact of mergers \& acquisitions on shareholders' wealth and efficiency
}

\author{
Tianqi Li \\ School of Economics, Shanghai University, Shanghai, China
}

\begin{abstract}
As nowadays mergers \& acquisitions are becoming more and more prevalent, this paper concerns the impact of mergers \& acquisition on shareholders' wealth and efficiency. Choosing mergers \& acquisitions events in bank industry, we apply literature analysis to see what previous scholars have found and CAPM model to calculate their CAR, which reflects the change of shareholders' values (positive CAR means shareholders gain positive returns from mergers \& acquisitions and vice versa). And finally, we find that bank mergers and acquisitions do create shareholder wealth for the target bank acquired and that in many cases the acquiring firm's shareholders tend to lose out because their ownership in the newly formed bank is severely diluted and the same is with the efficiency. What's more, when we take the financial crisis into consideration, mergers are seen to be a safe haven. Besides that, senior management must be skilled at corporate restructuring within the newly merged banks for merged banks to survive post-merger activity.
\end{abstract}

Keywords: mergers \& acquisitions; shareholders' wealth and efficiency; financial crisis

\section{INTRODUCTION}

This paper highlights motives for mergers and acquisitions within the banking industry in order to determine whether it increases the overall wealth of shareholders and whether a company's overall efficiency is improved. Empirical research analysis has been provided to indicate whether the effect of the Financial Crises of 2007 has positively caused merger activity to increase shareholder wealth and company efficiency.

For this paper we will use the definition of mergers and acquisitions as outlined by Arnold (2013). Mergers are 'the combining of two business entities under a common ownership'. The term for mergers and acquisitions is used interchangeably but acquisitions can be described as the coming together of roughly equal sized firms on roughly equal terms in which shareholders remain as joint owners. A takeover on the other hand is, 'the process whereby an acquiring firm makes a bid for a target company'. These terms will be used interchangeably throughout and will be referred to as 'mergers'.

\section{LITERATURE REVIEW}

\subsection{General empirical view}

Many empirical studies suggest that the general view is that mergers tend to increase shareholder wealth but decreases efficiency for the target firm. Inversely shareholder wealth is decreased for an acquiring firm as an excessive bid premium is paid over the pre-bid price in order to persuade target shareholders to sell their shares to the acquiring firm. This being said the acquiring firm is more likely to see an overall increase in efficiency. This is largely due to substantial cost cutting by removing duplicate processes when firms have merged (Glen Arnold, 2013).

Each bank has a different motive for participating in merger activity. For example, due to unforeseen economic circumstances in 2007 it was seen as a strategic move for banks to merge so that smaller banks could operate within the foreseeable future and avoid bank runs (Sharma, 2009). An example of this is Bear Stearns Bank acquired by JP Morgan and Chase Co in 2007. 
Table 1.Overview of efficiency study results

\begin{tabular}{lllllll}
\hline Reference (year) & Period & Sample size & Regional Focus & Overall & Cost Efficiency & Profit Efficiency \\
\hline Shaffer (1993) & $1984-1989$ & 20,503 & USA & Mixed & Mixed & NA \\
Fixler and Zieschang (1993) & 1986 & 160 & USA & Negative & Negative & NA \\
Berger and Mester (1997) & $1990-1995$ & NA & USA & Positive & Positive & Positive \\
\hline
\end{tabular}

Source: EDITED. By Kolaric and Schiereck, 2014

\subsection{Bank motives for mergers and acquisitions}

Oladipupo and Okafor (2011) explain that increasing shareholders' wealth is the fundamental purpose of mergers and acquisitions. Nonetheless there are many more motives.

(1) Synergy. Synergy is the most common motive whereby the value of two firms combined is greater than one. Synergy amalgamates duplicate costs by replacing identical processes acquired from the target firm and can be considered that the merged organization could exceed the profits of the original company by reducing costs or increasing the average income (Shaver 2006).

(2) Tax benefits. Companies can reduce taxes when merged. Tax benefits can accrue at both the corporate and at shareholder levels (Auerbach and Reishus, 1987). For example, acquiring firms can claim back their earnings losses when used to offset against the taxable profits from obtaining a target firm (Ghosh, A 2004) and shareholders can benefit by receiving profits when selling their shares during the process of the merger.

(3) Cost savings. Cost saving motives also drive the merger activity according to Badik (2007). For example, having a diversified production strategy will reduce operational costs. This diversification leads to new sources of cash flow because the merger will by nature increase and enhance the range of bank products and services available to customers as new markets are entered.

\subsection{Legal restrictions and cross border mergers and impact on efficiency}

Legal restrictions can also impact the efficiency of banks and limit competition. A country's characteristic is an important determinant of cross border mergers and acquisition activities. They suggest that cost inefficient banks are more prone to being cross-border acquired by foreign firms. Banks which suffer from geographic limitation will have higher cost efficiency and lower profit efficiency than other banks according to Berger and Mester (1997).

Legal restrictions play a key role in the international merging activity of banks and are becoming a more common means of accomplishing financial goals. Due to its success an increasing number of countries are adopting competition laws (Fugina, 2005) to reduce the monopolistic effects of mergers on the economy. Every country has different regulations and legal frameworks, which could affect the success of merger and acquisition activities. According to the empirical research, many mergers and acquisitions are concentrated in the United States of America and United Kingdom (Dilshad, 2013).

\subsection{The influence of bank mergers and acquisitions on shareholder wealth and efficiency}

Empirical evidence shows the effect on cost and profit efficiency.

Table 1 shows the results of many efficiency studies which links improvement opportunities for banks cost and profit efficiency. The majority studies focus on bank's cost efficiency and show little cost efficiency improvement from mergers in the 1980s. On average mergers in the 1980's show 5\% of cost efficiency or less (Berger and Humphrey, 1992; Rhoades, 1993; and Peristiani, 1997).

Further studies according to Fixeler and Zieschang (1993) show that the cost efficiency is negative and have been deteriorated in the study of 160 mergers in the period 1986 in the USA. This result might be due to the methodology that Fixler and Zieschang (1993) used where they used Törnquist productivity indices to describe the results of M\&A operations. On the other hand, the studies of Berger and Mester (1997) and Al-Sharkas et al. (2008) show a positive result in cost efficiency during 1990-1995. This could be due to technological advances which lead to improvements in cost efficiency for the combined entity. In addition to the study of Shaffer (1993), more than 20,000 hypothetical mergers shows a mixed result in the period of 1984-1989, but there are still some positive results for smaller bank mergers which achieved significant improvements in cost efficiency despite mostly negative results according to Fixeler and Zieschang (1993).

Aside from the studies above, banks might find it more difficult to achieve performance efficiency through mergers if they cannot diversify into mature banking markets within developed countries. Therefore banks tend to be more successful when they deal in emerging markets as they can diversify the product range and obtain new potential customers (Kolaric and Schiereck, 2014). 


\section{EMPIRICAL ANALYSIS}

\subsection{Establishment of Model}

Theoretically a successful acquisition will increase both acquiring and target banks share price. According to Fama et al. (1969), the shareholder's wealth in value change or abnormal return is the excess return of the expected one. Using the market model (Brown and Warner, 1985; Fama and French, 1993), the expected return that can be calculated for shareholder's wealth post-merger is:

\section{$\mathrm{Re}=\mathrm{R}$ riskfree $+\beta($ Rmarket-Rriskfree $)$}

Where $R$ (market) is industry average return on equity, $\beta$ is model parameters.

Abnormal return: $\mathrm{AR}=\mathrm{Rreal}-\mathrm{Re}$

Where Rreal is actually return.

\subsection{Specific Analysis}

This section of the essay examines a few different studies with different sample selections and time horizons using the CAPM model to calculate the culumative abnormal return (CAR) to reflect the change of shareholders' value.

In practice, Finkelstein (2009) states that the CAR of acquiring shareholder value in 2004 from US banking M\&A cases in the period of 1989-2001 is $-0.003 \%$, which means the investors of acquiring firms obtain negative returns from M\&A deals. This may be due to moral hazard whereby managers are likely to pay a higher premium to stimulate a greater operating efficiency, which may decrease the share value (Chronopoulos and Girardone, 2012). In addition, the increase of share value may be offset by the adding of complex organizational processes or blooming management cost (Greve, 1999).

However, the studying of Choi et al., (2010) shows a positive average CAR of acquiring shareholder in worldwide banking M\&A from 1995-2002. The difference between these two studies indicate that geographic specialization may lead to a gain or loss for acquiring banks in M\&A. For emerging countries, acquirers may need to add a high-risk premium to avoid solvency risk; for industrial countries a restrictive legal environment may increase the transaction cost resulting in a negative CAR (Berger et al., 2000).

For the target banks shareholders, 27 out of 28 event studies suggest that the CAR is poisitive (Kolaric. and Schiereck, 2014). This is due to higher market value evalution of the target's assets and a higher premium paid for good will of the target, thus the share value of target company will gain significantly in the short term when the merger or acquisition annouced. As for the long term the CAR of a target bank is positively related to size differences, potiential asset growth, bidding premium and complementary product, while negative $\mathrm{CAR}$ is related to a high capital ratio which indicates that management are not using capital efficiently and the potential cost increases (Ismail and Davidson, 2007). Addtionally, according to Chuang (2014), the gain of share value for a target bank is limited by information asymmetry. A perceived merger has little effects on stock market value while a slow market reaction can contribute to potential stock value increases.

However in the case of a hostile takeover Baradwaj et al., (1990) point out that a hostile takeover CAR of $30.32 \%$ is higher than a non-hostile takeover target CAR of $14.35 \%$ within a 60 day period. Nevertheless the acquiring bank will receive a value that is no more negative than the CAR gained from a normal M\&A. This reflects a more positive net wealth effect when selling the target assets at a lower price, which reduces the potential gain.

Also, in and post the crisis period, the CAR of bank merger may not be positive in emerging countries where the financial market is not fully liberalized. From Soussa and Wheeler (2006), the bank M\&A show the CAR is not significant from zero in Asia. And after that, the result becomes negative (-0.41\%). Because banks M\&A in and post 1997 in less regulated banking systems are mainly led by government (Crouzille et al., 2008), the first priority of banks M\&A is reducing ripple effect of bank bankrupt and saving the credit of banking sector rather than considering about CAR.

Overall, studies suggest a positive CAR from $10 \%$ to $15 \%$ in target banks and a mixed result for acquiring shareholders. In addition, unusual M\&A like hostile buyout and M\&A in a crisis may result in a different change in shareholder value.

\subsubsection{The Financial Crisis 2007 and empirical studies and journal evidence to support positive} shareholder efficiency and wealth

The Financial Crises has been the most dramatic financial event to occur since the 1929 Great Depression. In Europe and the United States banks faced an approximate loss of $\$ 4.5$ trillion in their market capitalization. Merger activity increased after the crisis in 2007 by more than $\$ 500$ bn in order to save banks from financial ruin. In some cases it was thought that this was the only option for banks to operate within the financial market.

(1) Public authorities were obliged to save financial institutions in order to avoid a colossal breakdown of the worldwide banking industry. Large banks considered 'too big to fail' were aided by government funds in order to maintain market stability and prevent further market collapse.

(2) Bank mergers survived the crisis because many banks realized that geographical diversification would increase their services offered and thus introduce new sources of cash flow. Thus new markets opened up new sources of cash flow for banks.

(3) An effective way to reflect the valuation of a 
ICITCE 2015

Table 2.Overview of changes in shareholder value from $M \& A$

\begin{tabular}{|l|l|l|l|l|l|l|}
\hline \multirow{2}{*}{ Reference (year) } & \multirow{2}{*}{ Period } & \multirow{2}{*}{ Sample Size } & \multirow{2}{*}{ Area } & \multicolumn{3}{|c|}{ Average CAR } \\
\cline { 5 - 7 } & & & & Acquirer (\%) & Target (\%) & Combined Unit (\%) \\
\hline Finkelstein (2009) & $1989-2001$ & 2,204 & USA & Negative & N/A & N/A \\
\hline Choi et al (2010) & $1995-2002$ & 140 & Worldwide & Positive & N/A & N/A \\
\hline Kiymaz (2013) & $1989-1999$ & 207 & USA & Positive & Positive & N/A \\
\hline Baradwaj et al. (1990) & $1980-1987$ & 23 & USA & Positive & Positive & N/A \\
\hline
\end{tabular}

Source: EDITED. By Kolaric and Schiereck, 2014

bank is price-to-tangible book value multiple (P/TBV) As can be seen in Figure 1, in the US, the P/TBV multiple of large cap bank decreased significantly from $3.34 \mathrm{x}$ in 2007 to $1.61 \mathrm{x}$ in 2014 . The low P/TBV multiple gives banks a better opportunity to acquire high value target assets at lower expense, which stimulates bank M\&A. Therefore, it can be seen that the M\&A number and value increase significantly in post crisis period.

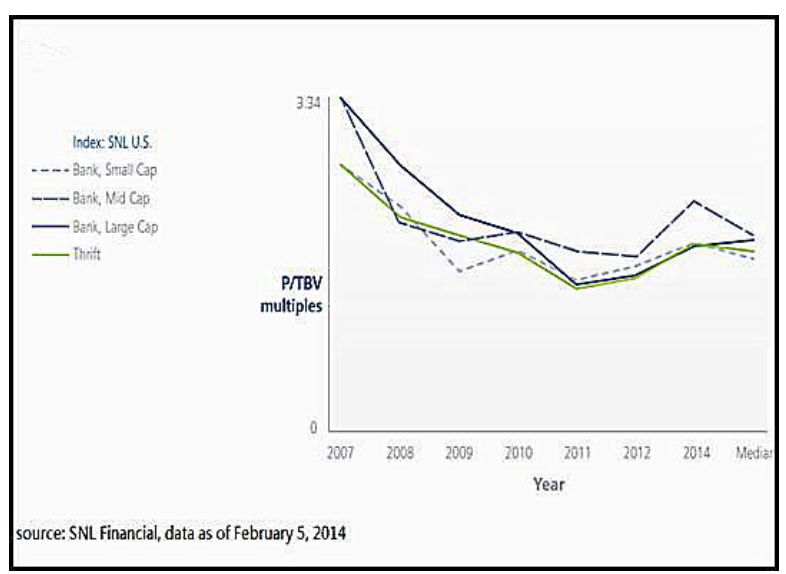

Figure 1. Financial data of P/TBV values from 2007 to 2014

\subsubsection{The winners and losers in mergers and acquisitions}

Warren Buffet describes the effect of M\&A as 'a bonanza for the shareholders of the acquirements; they increase the income and status of the acquirer's management; and they are a honey pot for the investment bankers and other professionals on both sides. But, alas, they usually reduce the wealth of the acquirer's shareholders, often to a substantial extent' according to Berkshire Hathaway Annual Report 1995.

An acquiring firm is said to lose out because it must pay a bid premium in order gain control of the target company and so its shareholders receive little or no gain. However the acquiring bank obtains a higher level of overall efficiency compared to the target bank because duplicate activities are eliminated according to Peristian (1997).

Third party winners include advisors, lawyers and investment bankers. They benefit by charging substantial fees to the acquiring banks in need of their professional and legal services in the smooth running of this business transaction.

\subsection{What makes a successful merger and why?}

In many cases mergers do not survive the extensive process. This is caused by differences in corporate culture and management styles, the excessive bid price paid, fail to take into account the new and existing customer base as well as a lack of strategic fit.

In order for mergers to be successful, acquiring banks must have extensive knowledge on the target firm and analyze the new markets that they will enter. Acquiring banks should also be prudent and assess their financial standing within the current financial climate before any acquisitions are made. Managers must make use of effective communication channels within the merged firm, which will enhance corporate culture and maximize efficiency.

\section{CONCLUSION}

There is a great deal of debate as to whether the topic of mergers and acquisitions creates shareholder value and increases efficiency in banks post-merger. The evidence and empirical studies outlined above show that bank mergers and acquisitions do create shareholders' wealth for the target bank acquired and that in many cases the acquiring firm's shareholders tend to lose out because their ownership in the newly formed bank is severely diluted. However the opposite is true for efficiency whereby the target bank will lose efficiency when acquired and the acquiring bank will gain efficiency due to synergy.

After the financial crisis, studies suggest that bank mergers play a pivotal role on the global financial system and its stability. The cause of the crisis and the impact of it have meant that mergers still continue to increase and that merger activity has increased instead of decreased. We have come to conclusion that for many banks to survive the initial period, mergers were the option of last resort.

The increase directly after the crises shows us that in order for banks to operate in the best interest of their clients and avoid a bank run like Northern Rock in 2007 to avoid bankruptcy, means that mergers were seen to be a safe haven especially when bailed out by government funds although this might have caused moral hazard problems.

We can also conclude that for merged banks to survive post-merger activity like JP Morgan Chase Co that senior management must be skilled at corporate 
restructuring within the newly merged bank. This is so that costs may be recovered through synergy and cost reducing techniques to enhance future efficiency and shareholder wealth for shareholders.

\section{ACKNOWLEDGEMENT}

I would like to take this opportunity to show my sincere gratitude to my supervisor, Dr Gui, who is very nice and knowledgeable, as well as provides me with important guidance about my article. I would also extend my thanks to all the other teachers who have helped me with this essay. Last but not least, I'd like to thank all my friends, especially my boyfriend and three roommates, for their support and encouragement.

\section{REFERENCES}

[1] Alan J. Auerbach \& David Reishus. 1987. Mergers and Acquisitions, Chapter 4: The Impact of Taxation on Mergers and Acquisitions, University of Chicago Press.

[2] Al-Sharkas A.A., Hassan M.K. \& Lawrence, S. 2008. The impact of mergers and acquisitions on the efficiency of the US banking industry: Further evidence. Journal of Business Finance and Accounting, 35: 50-70.

[3] Arnold G. 2013. Corporate Financial Management, Chapter 20 Mergers. England: Pearson Essex.

[4] Badík M. 2007. Motives and reasons of the bank mergers in the EU, 11th International Conference on Finance and Banking: Future of the European Monetary Integration, pp. 57-69, Business Source Complete, EBSCOhost, viewed 18 November 2014.

[5] Baradwaj B., Fraser D. \& Furtado, E. 1990. Hostile bank takeover offers, Journal of Banking and Finance, 14(6): 1229-1242, Business Source Complete, EBSCOhost, viewed 13 December 2014.

[6] Berger A.N., DeYoung R., Genay H. \& Udell G.F. 2000. The globalization of financial institutions: Evidence from cross-border banking performance. Brookings-Wharton Papers on Financial Services. 3: 23-125.

[7] Cetorelli N.H., B, Morgan D.P., S. \& Santos J. 2007. 'Trends in financial market concentration and their implications for market stability, Economic Policy Review (19320426), 13(1): 33-51, Business Source Complete, EBSCOhost, viewed 18 November 2014.

[8] Choi S., Francis B. \& Hasan I. 2010. Cross-border bank M\&As and risk: Evidence from the bond market, Journal Of Money, Credit and Banking (WileyBlackwell), 42(4): 615-645, Business Source Complete, EBSCOhost, viewed 13 December 2014.

[9] Chronopoulos D., Girardone C. \& Nankervis, J. 2013. How do stock markets in the US and Europe price efficiency gains from bank M\&As?, Journal of Financial Services Research, 43(3): 243-263, Business Source Complete, EBSCOhost, viewed 13 December 2014.
[10] Chuang K. 2014. Financial advisors, financial crisis, and shareholder wealth in bank mergers, Global Finance Journal, 25(3): 229-245, Business Source Complete, EBSCOhost, viewed 13 December 2014.

[11] Crouzille C., Lepetit L., \& Bautista C. 2008. How did the Asian stock markets react to bank mergers after the 1997 financial crisis?, Pacific Economic Review, 13(2): 171-182, Business Source Complete, EBSCOhost, viewed 13 December 2014.

[12] Cybo-Ottone A. \& Murgia M. 2000. Mergers and shareholder wealth in European banking, Journal of Banking and Finance, 24(6): 831-859.

[13] David H., Stephen R., Randolph W. \& Jeffrey J. 2010. Corporate Finance: European Edition ( $1^{\text {st }}$ edition), McGraw-Hill Higher Education, pp.808.

[14] Do announcements of bank acquisitions in emerging markets create value? (2007) Bank of England Quarterly Bulletin, 47(1): 86, Business Source Complete, EBSCOhost, viewed 13 December 2014.

[15] Fama E., Fisher L., Jensen M. \& Roll, R. 1969. The adjustment of stock prices to new information, International Economic Review, 10(1): 1, Business Source Complete, EBSCOhost, viewed 13 December 2014.

[16] Fama E, \& French K. 1993. Common risk factors in the returns on stocks and bonds, Journal of Financial Economics, 33(1): 3-56, Business Source Complete, EBSCOhost, viewed 13 December 2014.

[17] Finkelstein S. 2009. The effects of strategic and market complementarity on acquisition performance: Evidence from the US commercial banking industry, 1989-2001. Strategic Management Journal, 30(6): 617-646.

[18] Greve H.R. 1999. Branch systems and nonlocal learning in populations. In Advances in Strategic Management: Population Level Learning and Industry Change, Miner AS, Anderson P (eds). JAI Press: Greenwich, CT; pp. 57-80

[19] Ismail A. \& Davidson I. 2007. The determinants of target returns in european bank mergers, Service Industries Journal, 27(5): 617-634, Business Source Complete, EBSCOhost, viewed 12 December 2014.

[20] Kiymaz H. 2013. Cross-border mergers and acquisitions and country risk ratings: Evidence from U.S. financials, International Journal of Business and Finance Research, 7(1): 17-29, Business Source Complete, EBSCOhost, viewed 13 December 2014.

[21] Kolaric S. \& Schiereck D. 2014. Performance of bank mergers and acquisitions: a review of the recent empirical evidence, Management Review Quarterly, 64(1): 39-71.

[22] Oladipupo A.O. \& Okafor C.O. 2011. Control of shareholders' wealth maximization in Nigeria, The Journal of Business Systems, Governance and Ethics. [retrived 10th December, 2014] from Ebschost Business Source Premier database.

[23] Reed S.F., Lajoux A. \& Nesvold H.P. 2007. The Art of M\&A, Fourth Edition: A Merger Acquisition Buyout Guide, McGraw Hill Professional. 